Marine Research in Indonesia No. 18, 1977 : $63-72$.

\title{
ADAPTATIONS OF DECAPOD CRUSTACEANS TO LIFE IN MANGROVE SWAMPS
}

\author{
by
}

\author{
D.F. MALLEY ${ }^{1)}$
}

\begin{abstract}
Decapod crustaceans such as sesarmid and ocypodid crabs and thalassinid lobsters are conspicuous in numbers and bio mass on the mangrove swamp floor. An understanding of their biology and physiology is concomitant with a full understanding of their role in swamp ecology and management and for controlling them when they are pests or for augmenting their usefulness. The swamp environment of decapods is essentially a moist, low oxygen (in standing water), very broad intertidal habitat with an abundant food source available in angiosperm tissue. Present knowledge of the biology of mangrove decapods will be briefly summarized, such as feeding, respiratory, reproductive and behavioural adaptations, and including reports on feeding by Chiromanthes spp. in Malaysian swamps. In addition, the paper will attempt to identify fruitful areas for physiological and ecological research such as metabolic adaptations to angiosperm diet.
\end{abstract}

Decapod crustaceans are a group which has successfully colonized the marine intertidal zone worldwide with the exception of the Antarctic. Tropical mangrove swamps have a particularly large and conspicuos representation. While a great deal is known of the physiology and behaviour of many intertidal invertebrates (SOUTHWARD 1965; VERNBERG \& VERNBERG 1972), the fauna of mangrove swamps has been much less studied with regard to these aspects (MACNAB 1968; VAN TINE \& SNEDAKER 1974). Yet these swamps, while they have much in common with other intertidal habitats, also possess a number of distinctive features by virtue of their sylvan nature and geographical location on tropical low energy shores usually in high rainfall areas. The purpose of this paper is to examine adaptation of decapods to the distinctive aspects of mangrove swamps, a study which may increase our understanding of physiological and behavioural diversity within this group of animals. Knowledge of the biology of swamp decapods may in turn allow us to manage useful species better and to control pest species more effectively.

The following five characteristics of mangrove swamps, though not all unique to this environment, are here judged as the ones of particular

1) Freshwater Institute, 501 University Crescent, Winnipeg, Manitoba Canada R3T 2N6. 
relevance to decapods :

1. Alternating tidal inundation and exposure to air and possible desiccation is characteristic of all intertidal environments. In mangrove swamps, which occupy only the upper half of the intertidal zone, frequency of tidal inundation may vary from twice each day on the seaward side to only a few times per year on the landward side (MACNAE 1968). Nevertheless, mangrove swamps are relatively moist intertidal environments. The climate in regions where the swamps are well-developed is generally humid, with high rainfall. For example, the relative humidity on the west coast of peninsular Malaysia is high year round varying between 81 and $85 \%$ (SASEKUMAR 1974). The forest canopy further reduces the desiccating property of this inter tidal habitat by reducing exposure of the swamp floor to direct sun light and wind.

2. Widely variable salinity of available water from extremes of $0 \%$ o to $45 \%$ o (WALSH 1974), influenced by amount of rainfall, frequency of tidal inundation, proximity to river or stream and amount of eva poration.

3. Low $\mathrm{O}_{2}$ concentrations in soil water and atmosphere (CHAPMAN 1944) due to high organic content and low porosity of the mud. Mangrove swamps are best developed on shores receiving an allochthonous source of silt rich in organic matter as from the tropical rain forest (WATSON 1928; WALSH 1974). In an established swamp the organic matter is derived autochthonously as well. Bacterial break down of the organic matter depletes $\mathrm{O}_{2}$ from all but the upper few milimeter of the mud, aeration of the soil is very slow, and further decomposition occurs aerobically, resulting in the production of sulphides and elemental sulphur (RICKARD 1973).

4. Extreme width relative to other intertidal types, e.g. up to twelve miles wide in peninsular Malaysia (WATSON 1928).

5. Plentiful potential food source in the form of angiosperm tissue, e.g. leaves, flowers, fruits, seedlings, stems, pneumatophores.

The decapods of mangrove swamps belong predominantly to two .brachyuran families, Grapsidae and Ocypodidae (MAC NAE 1968; SASEKUMAR 1974). Most of the grapsids fall into the subfamily Sesarminae. One group within this subfamily composed of Sesarma and 21 closely related genera (SERENE and SOH 1970; SERENE unpublished keys) are crabs almost totally restricted to mangrove swamps (CAMPBELL 1967). These are referred to below as "sesarmids". In the Indo-Pacific alone this 
group includes more than 100 species. A third family, Portunidae, is conspicuously represented by the commercially-important edible crab, Scylla serrata. Crabs of the family Xanthidae occur on eroding swamp shores. Also conspicuous are members of the macruran family, Thalassinidae (Thalassina, Upogebiq) as Well as natant alpheid shrimps (family Alpheidae) (MACNAE 1968).

Decapods inhabiting the intertidal and supralittoral face a number of general problems of which continuance of reproduction and early development and regulation of temperature, salts and water are identified by BLISS (1968) as the most important ones. Our attention here is oil respiratory, feeding, digestive and reproductive adaptations which appear to be specific to life in mangrove swamps. Thus although salt and water balance in the face of variable salinity and periodic exposure to air are vital to swamp decapods, mechanisms of osmotic and ionic regulation are not expected to be different in the swamp from those in other intertidal habitats and will not be considered further.

\section{Adaptations to Limited Water Availability}

Although the swamp floor may be exposed to air for considerable periods of time, water is available in limited quantities as standing water or from the burrows which extend down to the water table. Some of these decapods have remained essentially aquatic, retaining water as the respiratory medium, but have evolved means of coping with limited water for ventilation. One well-described adaptation characteristic of the sesarmids is conservation of branchial chamber water by its recirculation. Water from the branchial chamber is passed out of the exhalent opening in front of the mouth, then by several routes over the branchiostegite and back into the chamber via the inhalent openings above bases of the limbs. The water is oxygenated in the process and this is aided by the unique sesarmid character of a well-developed reticulation of intercrossing lines of setae on the branchiostegite (VERWUY 1930; MAC NAE 1968).

A different strategy is shown by the ocypodid crabs which unlike the sesarmids are found in a wide variety of intertidal and estuarine habitats. As a family they are amphibious (BLISS 1968) showing greater use of air as the respiratory medium. Adaptations include stiffening and reduction in surface area of the gills, vascularization of the wall of the branchial chamber for use as a lung and pumping of air through the water in the branchial chamber for oxygenation (MACNAE 1968). It is probably no accident that the sesarmids which have very successfully colonized the intertidal zone 
while remaining essentially aquatic are restricted to mangrove swamps which are moist and have a relatively good supply of free water. On the other hand, the ocypodids have become more independent of free water and occur on a wide variety of sediment shores.

\section{Adaptations to Low Oxygen Concentrations}

Remarkably few values are reported in the literature for the concentrations or availability of $\mathrm{O}_{2}$ in various microhabitats in mangrove swamps and at various times during the tidal cycle. CHAPMAN (1944) reports $\mathrm{O}_{2}$ concentrations in swamp soil atmosphere to be usually less than half that in air, e.g. 2.3 to $6 \%$ compared with $20.99 \%$ in air. In a mangrove-bordered lagoon in Puerto Rico, MATTOx (1949) found that dissolved $\mathrm{O}_{2}$ was lowest $(3.5 \mathrm{ml} / \mathrm{l})$ in late summer and highest $(7 \mathrm{ml} / \mathrm{l})$ in winter. For comparison, in this study, open bay water at $37 \%$ o salinity and $25^{\circ} \mathrm{C}$ contained 8.5 $\mathrm{ml} / 1 \mathrm{O}_{2}$. WALSH (1967) studied a watercourse through a young mangrove swamp in Hawaii and found dissolved $\mathrm{O}_{2}$ values to be from an undetectable amount to $1.69 \mathrm{ml} / 1$ at the landward side of the swamp and from 0.92 to $6.53 \mathrm{ml} / 1$ at the seaward edge. Saturated water at $34 \%$ salinity and $25^{\circ} \mathrm{C}$ contains $4.95 \mathrm{ml} / \mathrm{l} \mathrm{O}_{2}$ (SVERDRUP et al 1949). Oxygen concentration in the Hawaiian swamp varied seasonally with highest values in the spring and late fall. There was also considerable diurnal variation in $\mathrm{O}_{2}$. Microbial decomposition of organic matter thus depletes $\mathrm{O}_{2}$ not only from the soil but also from the soil atmosphere and from shallow flowing or standing water on the swamp floor.

Additional information is very much needed on $\mathrm{O}_{2}$ concentrations or availability particularly from the extensive, climax forests of the tropics and from various microhabitats such as in pools of standing surface water, in burrow water and air, in creeks and streams. Variation should be monitored over time during the tidal cycle, over 24 hours, seasonally and across vegetation zones and soil types.

In the swamp environment where anoxic or low $\mathrm{O}_{2}$ conditions are characteristic, it is reasonable to examine decapods for the ability to metabolize anaerobically over short periods such as a portion of the tidal cycle or even for more extended periods. Anaerobic metabolism for long periods without the incurrance of an $\mathrm{O} 2$ debt is known to occur in certain intertidal annelids and bivalves (for reviews see VERNBERG \& VERNBERG 1972; HOCHACHKA \& SOMERO 1973). In contrast, in the crustaceans description of anaerobic metabolism and its mechanisms is still in its infancy. Two species have been documented to exist indefinitely in low $\mathrm{O}_{2}$ or anoxic 
waters but nothing is known of the mechanisms involved. The copepod Calanus plunchrus lives in the oxygen minimum layer of some temperate oceanic waters. In the laboratory this species has been maintained for two weeks in $\mathrm{O}_{2}$-free water and is not sensitive to low concentrations of cyanide (LiTTLEPAGE, pers. comn.). A species of amphipod tentatively identified as Orchomenopsis obtusa has been observed in and collected from the anoxic zone at the bottom of a British Columbia inlet (SILVER, pers. comm.). This population migrates vertically but appears to remain permanently within the anoxic zone (LITTLEPAGE pers. comm.).

In the decapods, anaerobic metabolism over indefinite periods has not yet been described, but several intertidal species experience low $\mathrm{O}_{2}$ conditions during part of the tidal cycle. The crabs Uca spp and Sesarma cinereum on temperate muddy shores metabolize anerobically under low $\mathrm{O}_{2}$ or anoxia occurring in the burrow water during low tide. They mobilize glycogen and accumulate lactate which is broken down when oxygenated conditions return when the burrow water is flushed by the high tide (TEAL \& CAREY 1967). Two other decapods, mud shrimps belonging to the family Thalassinidae, Callianassa californiensis and Upogebia pugettensis, burrow in intertidal muddy bottoms of temperate shores. Both can survive anoxic conditions in the laboratory from 32 to 138 hours. Following return to oxygenated conditions, oxygen consumption is elevated above pre-anoxic rates indicating that an $\mathrm{O}_{2}$ debt had developed (THOMPSON \& PRITCHARD 1969). These produce high levels of lactate but also appear to produce $\mathrm{CO}_{2}$ which suggests that metabolic pathways beyond glycolytic fermentation are being used for anaerobiosis (COUSENS 1974; pers. comm.). Thus in apparent contrast to the annelids, bivalves, copepod and amphipod mentioned above, these decapods build a lactate- $\mathrm{O}_{2}$ debt under anoxic conditions and frequent return to oxygenated conditions is essential for continued existence.

Study of decapods in mangrove swamps may extend our knowledge of anaerobic metabolism in this group and the sesarmid and ocypodid crabs and the thalassinid mud lobster Thalassina anomala are appropriate candidates for study. The crabs are basically aerobic. When the swamp floor is exposed to air, sesarmids oxygenate the branchial chamber water by recirculating it over the carapace; ocypodids mix this water with the air that is in the branchial chamber and also use the chamber as a lung. Both groups are independent of the level of oxygenation of standing water. At these times, sesarmids such as Chiromanthes eumolpes and C. onychophorum move about on the swamp floor and ocypodids such as Uca spp. are frequently seen at the mouths of their burrows. When the swamp floor is 


\section{D.F.MALLEY}

tidally-inundated, many species retreat to their burrows to avoid aquatic predators and it is at these times that these decapods may have to turn to anaerobic pathways. One sesarmid, the large Neoepisesarma versicolor, has opted to avoid low $\mathrm{O}_{2}$ conditions by becoming more aerial. From personal observation, at low tide it sits at the entrance, of the burrow but when the tide advances, it climbs out of the burrow and clings to the trunks of trees.

If a decapod should exist which can live under very low $\mathrm{O}_{2}$ conditions for periods longer than the tidal cycle, it may well be the mud lobster Thalassina anomala, a mangrove swamp species which builds conspicuous mounds of earth up to more than a meter high around the entrance to the burrow. This species occurs in south and southeast Asia, Australia (MAC NAE 1968) and India (SANKOLLI 1963). Its burrows range in depth from about one to three meters and extend down to the water table. The entrance leading to the main burrow is generally plugged with layers of earth. The lobsters are rarely seen outside their burrows and indeed move poorly on the mud surface. Those living lowest in the intertidal zone are more or less completely submerged (SANKOLLI 1963) probably in poorly-oxygenated water. Their habit of burrowing deeply in anoxic mud, closing the mouth of the burrow which would reduce movement of air through it and their secretive behaviour may mean that they do not have frequent access to welloxygenated conditions. The earliest literature on this species comments on its apparent adaptation to poorly aerated water. The branchiostegites are hinged to the dorsal portion of the carapace so that movements of these can rapidly clear water from the branchial chamber (PEARSE 1911) presumably for an increased rate of ventilation.

\section{Reproductive Adaptations}

With the exception of freshwater species, decapods, whether marine, semi-terrestrial or terrestrial, produce large numbers of eggs which hatch into larvae pelagic in the sea. Development proceeds in the sea through a considerable number of freeswimming stages (BLISS 1968). Reproductive adaptations in the swamp do not alter the pattern of larval development, rather they appear to be related to the extreme width of this intertidal environment, or in other words, the considerable distance to the sea for the release of the larvae. A mangrove tree-climbing sesarmid of North and South America, Aratus pisoni, synchronizes breeding and migrations to the sea with the lunar cycle (WARNER 1967). Eggs develop attached to the pleopods of the female and hatching is synchronized with new or full 
moon, particularly the latter. When the eggs are about to hatch females migrate to the seaward edge from deeper within the swamp and release the newly hatched larvae (prezoeae) into the sea. As a further adaptation, the eggs carried by a female hatch simultaneously ensuring that the female spends a minimum of time in the water shaking off the new larvae, a time when it is vulnerable to predators.

Lunar periodicity of breeding cycles in decapods has been reported in only one other species, the land crab Cardisoma guanhumi (GIFFORD 1962'). Here hatching of the eggs occurs almost entirely at the time of full mpon. WARNER (1967) suggests that Cardisoma living inland has only one signal, the full moon, each month to trigger breeding rhythm whereas Aratus living close to the sea is triggered by the two spring tides each month. Perception of lunar (once per month) or tidal cycles (twice per month) provides a signal to swamp species which may be detected far inland, and which allow females to time their migrations so that when the eggs are ready to hatch they will be at the seaward edge of the swamp. Also the spring tides occurring at the time of the hatching are most favourable for the dispersal of the larvae. It would be interesting to examine whether other species of swamp decapods breed and migrate to the sea with a lunar periodicity. And if so, whether those species living highest in the intertidal zone which may be inundated only a few times per year depend more upon the full moon signal than upon the tidal one.

Another adaptation which deserves further examination is the possibility that certain species suppress the marine pelagic habit of the larvae and retain the larvae in the burrow (MAC NAE 1968). According to MAC NAE, TWEEDE found larvae of the small ocypodid Ilyoplax delsmani in burrows. This strategy may be important for small or relatively sedentary species or for species far inland to ensure that the necessary aquatic environment for larval development is available independently of tidal inundation and without extensive migration by the adults.

\section{Feeding and Digestive Adaptations}

Most of the primary production and standing crop of a mangrove swamp is in the form of angiosperm tissue (GOLLEY, ODUM \& WILSON 1962). This potentially can serve as a food source either directly by grazing or consumption of freshly fallen litter, or after breakdown to detritus. According to the literature few decapods are herbivorous or vegetarian, although this type of nutrition is common for planktonic crustaceans, amphipods and isopods (MARSHALL \& ORR 1960). Almost all decapods are predators, scavengers, omnivores or detritus feeders. One of the herbi- 


\section{D.F.MALLEY}

vorous decapods is the kelp crab, Pugettia producta which feeds primarily on kelp (HEWAT 1937; LEIGHTON 1966). Thalassina anomala has been considered to eat land vegetation (PEARSE 1911) but this has been refuted by JoHnSON (1961) and SANKOLLI (1963). Instead T. anomala appears to be a mud feeder functioning like an earthworm. The sesarmids Sesarma curacaoense and S. ricordi, inhabitants of mangrove swamps in Florida are detritus feeders according to ABELE (1973). Thus, although a vegetarian existence is uncommon for a decapod, it is not unknown, and it is not surprising to find that the diet of at least two species of sesarmids in Malaysian mangrove swamps consists almost entirely of mangrove leaf material. Stomach contents of Chiromanthes onychophorum and C. dussumieri were estimated by volume to be 91 to $96 \%$ mangrove leaf tissue with very small amounts of animal remains, diatoms, silt and unidentified material (MALLEY 1975). These species in the laboratory will consume fresh green leaves of Avicennia but the appearance of the stomach contents of animals from the field suggests that the crabs in nature are not grazers but rather are eating leaf litter. It is not yet known what proportion of the nutrition comes from the angiosperm tissue as opposed to the microflora associated with decomposing leaf tissue. The capability of swamp crabs to digest angiosperm tissue is therefore suggested as another area for further investigation.

There have been several reports that cellulase is secreted by the decapod hepatopancreas, e.g. in Astacus fluviatilis and Homarus vulgaris (KOOIMAN 1964) and others (Panulirus japonicus, Procambarus clarkii, Calappa, Pachygrapsus) although there is not total rejection yet of the possiblity that microorganisms and not the decapods are producing the cellulase (VAN WEEL 1970). It is possible that further exploration of feeding and digestion in various species of swamp decapods will broaden our understanding of diversity within the crustaceans with respect to food items utilized, digestive and enzymatic adaptations, e.g. whether decapods produce cellulase endogenously and what nutritional role cellulose plays in the decapod diet.

Consumption of fresh leaf litter by sesarmids suggests that they may have overcome the problem of tannins. Tannin is an important constituent of all parts of mangrove trees (WALSH 1974). They are strong proteinbinders and are thought to account for the fact that there is little grazing by insects on mangrove leaves. Whether sesarmids in nature select leaf material which has been leached of tannin, or select plant species which are lowest in tannin or can physiologically cope with the tannin are all questions. 
In summary, perhaps much can be learned of the adaptive radiation of decapod crustaceans by study of tropical mangrove swamp species since the swamp is a distinctive intertidal environment by virtue of its relatively moist conditions, low dissolved $\mathrm{O}_{2}$ levels, great horizontal distances and plentiful angiosperm food sources. The great diversity of species inhabiting this environment make the prospects doubly interesting. Where it is desired to manage the numbers or distribution of decapods, such as for pests, the mound-building Thalassina anomala or seedling-eating crabs, or for edible species, appropriate methods may suggest themselves as more of their biology is understood. For example, identification of those crabs which are herbivorous will help to pinpoint those responsible for seedling damage. Litter-consuming species may usefully be encouraged in conjunction with a ring of mangroves around fish and prawn ponds to provide an added input to the pond food chains in the form of detritus. Knowledge of the oxidative metabolism of the mud lobster may suggest chemical ways of inhibiting metabolism or slight alterations in the burrow atmosphere which would eliminate this species when desired.

\section{REFERENCES}

ABELE, L.G. 1973. Taxonomy, distribution and ecology of the genus Sesarma (Crustacea, Decapoda, Grapsidae) in Eastern North America, with special reference to Florida. Amer. Midland Natur. 90 : 375 - 386.

BLISS, D.E. 1968. Transition from water to land in decapod crustaceans. Amer. Zool. 8 : 355-392.

CAMPBELL, B.M. 1967. The Australian Sesarminae (Crustacea : Brachyura): Five species of Sesarma (Chiromantes). Mem. Queensland Mus. 15: 1 - 20.

CHAPMAN, V.J. 1944. 1939 Cambridge University Expedition to Jamaica. - Part 3. The morphology of Avicennia nitida JACQ. and the function of its pneumatophores. $J$. Linnean Soc. (London). Bot. 52 : 487 - 533.

COUSENS, N.B.F. 1974. Some physiological and behavioural adaptations to anoxic tolerance in the burrowing shrimp, Upogebia pugettensis (DANA). Abstracts of Symposia and Contributed Papers of Western Society of Naturalists 55th Annual Meeting, Dec. 27 - 30, 1974, Vancouver.

GIFFORD, C.A. 1962. Some observations on the general biology of the land crab, Cardisoma guanhumi (LATREILLE), in south Florida. Biol. Bull. mar. biol. Lab., Woods Hole 123 : $207-223$.

GOLLEY, F., H.T. ODUM and R.F. WILSON 1962. The structure and metabolism of a Puerto Rican red mangrove forest in May. Ecology 43: 9 - 19 .

HEWAT, W.G. 1937. Ecological studies on selected marine intertidal communities of Monterey Bay, California. Amer. Midland Natur. 18: 161 - 206.

HOCHACKA, P.W. and G.N. SOMERO 1973. Strategies of Biochemical Adaptation. W.B. Saunders Co., Philadelphia. 357 pp.

JOHNSON, D.S. 1961. The food and feeding of the mud-lobster, Thalassina anomala (HERBST) Crustaceana 2: $325-326$. 
KOOIMAN, P. 1964. Carbohydrases of hepatopancreas of crayfish and lobster. J. Cell. Com. Physiol. 63 : 197 - 201.

LEIGHTON, D.L. 1966. Studies of food preference on algivorous invertebrates of southern California kelp beds. Pacific Sci. 20: 104 - 113.

MACNAE, W. 1968. A general account of the fauna and flora of mangrove swamps and forests in the Indo-West-Pacific region. Adv. Mar. Biol. $6: 73-270$.

MALLEY, D.F. 1975. Detritus production in a tropical mangrove swamp : Role of sesarmid crabs. Abstracts of 38th Annual Meeting of the American Society of Limnology and Oceanography, June 23 - 26, Halifax.

MARSHALL, S.M. and A.P. ORR 1960. Feeding and nutrition. In : T.H. WATERMAN (ed.), The Physiology of Crustacea. Vol. 1, pp 227 - 258. Acedemic Press, New York and London.

MATTOX, N.T. 1949. Studies on the biology of the edible oyster, Ostrea rhizophorae GUILDING in Puerto Rico. Ecol Monogr. 19 : 339 - 356.

PEARSE, A.S. 1911. On the habits of Thalassina anomala (HERBST). Philippine J. Sci. 6: $213-217$.

RICKARD, D.T. 1973. Sedimentary iron sulphide formation. In H. DOST (ed.), Acid Sulphate Soils. 1: 28 - 65. Int. Inst. Land Reclamation and Improvement, Wageningen, The Netherlands.

SANKOLLI, K.N. 1963. On the occurrence of Thalassina anomala (HERBST), a burrowing crustacean in Bombay waters, and its burrowing methods. J. Bombay Natur. Hist. Soc. 60: 600 - 605.,

SASEKUMAR, A. 1974. Distribution of macrofauna on a Malayan mangrove shore. J. Anim. Ecol. $43: 51$ 69.

SERENE, R. and C.L. SOH 1970. New Indo-Pacific general allied to Sesarma SAY 1817 (Brachyura, Decapoda, Crustacea). Treubia 27: 387 - 416.

SOUTHWARD, A.J. 1965. Life on the Sea-shore. Harvard University Press, Cambridge, Mass. 153 pp.

SVERDRUP, H.U., M.W. JOHNSON and R.H. FLEMING 1947. The Oceans: Their Physics, Chemistry and General Biology. Prentice-Hall, Inc. Englewood Cliffs, N.J. 1087 pp.

TEAL, J.M. and F.G. CAREY 1967. The metabolism of marsh crabs under conditions of reduced oxygen pressure. Physiol. Zool. 40 : 83 - 91.

THOMPSON, R.K. and A.W. PRITCHARD 1969. Respiratory adaptations of two burrowing crustaceans, Callianassa californiensis and Upogebia pugettensis (Decapods: Thalassinidea). Biol. Bull. mar. biol. Lab. Woods Hole 136 : 274 - 287.

VAN TINE, M. and S.C. SNEDAKER 1974. A Bibliography of the Mangrove Literature. Prepared for the International Symposium on Biology and Management of Mangroves, Oct. 8-11, Honolulu. Institute of Food and Agricultural Sciences, University of Florida, Gainesville.

VAN WEEL, P.B. 1970. Digestion in Crustacea. In M. FLORKIN and B.T. SCHEER (eds.). Chemical Zoology. Vol 5. Part A. 97 - 115.

VERNBERG, W.B. and F.J. VERNBERG 1972. Environmental Physiology of Marine Animals. Springer-Verlag, New York. 346 pp.

VERWEY, J. 1930. Einiges uber die Biologie ostindischer Mangrovekrabben. Treubia 12 : 169-261.

WALSH, G.E. 1967. An ecological study of a Hawaiian mangrove swamp. In G.H. LAUFF(ed.), Estuaries. Amer. Assn. Adv. Sci. Publ. No. 83. 420 - 431.

WALSH, G.E. 1974. Mangroves: A review. In R. REIMHOLD and W. QUEEN (eds.), Ecology of Halophytes. Academic Press, New York and London. 51 - 174. WARNER, G.F. 1967. The life history of the mangrove tree crab, Aratus pisoni J. Zool. (London) $153: 321-335$.

WATSON, J.G. 1928. Mangrove forests of the Malay Peninsula. Malayan For. Rec. No. 6, 275 pp. 